Article

\title{
Dynamic Changes in Carbon Sequestration from Opencast Mining Activities and Land Reclamation in China's Loess Plateau
}

\author{
Boyu Yang ${ }^{1 \oplus}$, Zhongke Bai ${ }^{1,2, *}$, Yingui Cao ${ }^{1,2}$, Feng Xie ${ }^{1}$, Junjie Zhang ${ }^{1}$ and Yannan Wang ${ }^{1}$ \\ 1 School of Land Science and Technology, China University of Geosciences, No. 29, Xueyuan Road, \\ Haidian District, Beijing 100083, China; yangboyu1247@126.com (B.Y.); caoyingui@cugb.edu.cn (Y.C.); \\ 15846581960@163.com (F.X.); 2012150025@cugb.edu.cn (J.Z.); 3012180005@cugb.edu.cn (Y.W.) \\ 2 Key Lab of Land Consolidation and Rehabilitation, the Ministry of Natural Resources, Beijing 100035, China \\ * Correspondence: Baizk@cugb.edu.cn
}

Received: 19 January 2019; Accepted: 6 March 2019; Published: 10 March 2019

check for updates

\begin{abstract}
Opencast coal mining causes serious damage to the natural landscape, resulting in the depletion of the carbon sequestration capacity in the mining activity. There are few studies on the variation of carbon sequestration capabilities caused by land use changes in opencast mining areas. This paper uses six images were used to quantify the changes in land use types from 1986 to 2015 in the Pingshuo mining area in northwest China. At the same time, used statistical analysis and mathematical models to study soil and vegetation carbon sequestration. Results indicate that the total carbon sequestration exhibits a significant downward trend from $4.58 \times 10^{6} \mathrm{Mg}$ in 1986 to $3.78 \times 10^{6} \mathrm{Mg}$ in 2015, with the decrease of soil carbon sequestration accounting for the largest proportion. The carbon sequestration of arable land accounted for $51 \%$ of the total carbon sequestration in the mining area, followed by grassland (31\%) and forestland (18\%). Land reclamation contributed to the greatest increase in carbon sequestration of arable land from $17,890.15 \mathrm{Mg}$ (1986) to $27,837.95 \mathrm{Mg}$ (2015). Additionally, the downward trend in the carbon sequestration capacity of the mining ecosystem was mitigated after 2010 as the positive effects of land reclamation gradually amplified over time and as the mining techniques were greatly optimized in recent years in the Pingshuo mining area. Thus, terrestrial carbon sequestration can be improved through land reclamation projects and optimized mining activities. These results can help guide the utilization of reclaimed land in the future.
\end{abstract}

Keywords: land use management; driving factor; Pingshuo opencast mine; land-use change; sustainable development

\section{Introduction}

In 2015, the Chinese government submitted an emissions reduction plan to the Secretariat of the United Nations Framework Convention on Climate Change. The purpose of this program is to reduce $\mathrm{CO}_{2}$ emissions as soon as possible. The specific goal is to reduce $\mathrm{CO}_{2}$ emissions per unit of GDP by 2030 by $60-65 \%$ compared to 2005 values [1]. China is facing enormous challenges in energy conservation and emissions reduction. Excellent results have been achieved through long-term monitoring and regulation. According to official data, by the end of 2017, China had exceeded the 2020 emission reduction target. But the coal mining is an important industry in China; thus, reducing emissions and increasing carbon sinks in mining areas is the focus of many scholars. China's mining carbon emissions accounted for 8.61\% of the total industrial carbon emissions from 1999-2013 [2]. Implementation of land reclamation in mining areas significantly increase the carbon sequestration 
capacity of soil and [3]. Therefore, the study of carbon sequestration in mining areas is necessary for the achievement of the 2030 emissions target at an early time.

Carbon sequestration and $\mathrm{CO}_{2}$ flux estimation methods, guided by the Energy Independence and Safety Act of 2007, are primarily based on the carbon storage, carbon sequestration capacity and rate of $\mathrm{CO}_{2}$ flux in ecosystems [4]. In recent decades, fossil fuel combustion, land use changes and biomass burning have led to imbalances in the global carbon cycle and increased greenhouse gas emissions [5]. Therefore, it is very important to formulate strategies to increase carbon sequestration. One option for further research is carbon sequestration in terrestrial ecosystems [6]. Furthermore, some governments levy taxes on carbon emissions, which provide incentives for reforestation of agricultural land [7]. Soil and climate characteristics may lead to differences in vegetation succession [8-11]. For example, the content of soil organic carbon (SOC) content of an Ohio mining area in the first $0-5 \mathrm{~cm}$ of the soil layer was ordered as hay grassland $>$ pasture $>$ woodland, while in the first $0-30 \mathrm{~cm}$ it was ordered as hay grassland $=$ pasture $>$ woodland $>$ undisturbed woodland $=$ moderately disturbed arable land [12] .

Anthropogenic activities and human abuse of soil resources results in land degradation, which subsequently leads to a reduced ability to provide ecosystem services [13,14]. Land use changes and restoration of degraded land with soil amendments are considered effective strategies to enhance soil carbon sequestration [15-18]. In the United States and many European countries, perennial vegetation has been planted on degraded and destroyed land to increase the SOC content and to control soil erosion $[19,20]$. Similarly, China launched the "grain for green project" (GGP) in 1999 in order to protect ecosystem stability in regions with severe soil erosion [21]. Natural vegetation restoration may allow for a significant increase in SOC storage [22]. policymakers should consider the importance of using abandoned land for mitigating climate change when formulating reclamation plans [23]. Opencast coal mining drastically deteriorated local soil profiles and depleted soil nutrients, land reclamation accelerated the accretion of both SOC and labile organic carbon fractions in Pingshuo reclaimed mine soils [24].

Revegetation of degraded land with legume pastures, especially Medicago, in the semi-arid Loess Plateau play an important role in improving vegetation conditions, controlling soil erosion and enhancing SOC accumulation [25]. Carbon sequestration in opencast mining areas mainly comes from reclaimed forest and grassland, with $51 \%$ of the carbon pool in reclaimed land being stored in vegetation [26]. It was found that the soil carbon pool accounted for $94 \%$ of the total carbon pool for one year of forestland reclamation but the proportion decreased to $36 \%$ after more than 14 years of reclamation. In contrast, the proportion of the soil carbon pool in grassland reclamation was $95 \%$ in one year and $89 \%$ after more than 25 years [27]. The soil carbon pool of natural restored forestland in mining areas accounted for $21.8 \%$ of the vegetation carbon pool, while that of reclaimed forestland accounted for $98.1 \%$ of the vegetation carbon pool [28]. Forest ecosystems have strong carbon sequestration and carbon storage potential that can be offset by forest vegetation sequestration in high-emission areas [29]. The higher the original forest site quality, the less likely carbon sequestration potential was restored, and the greater the disparity between pre- and post-mining carbon sequestration stocks [30].

Emissions from fossil fuels and land-use changes now exceed ten billion tons or petagrams (Pg) of carbon per year, tracking the most carbon intense emission scenarios of the Intergovernmental Panel on Climate Change [31]. Opencast mining, the most common coal mining technique worldwide, accounts for $15 \%$ of the coal output in China [32]. Compared to underground mining, this mining technique usually damages 2-11 times more land [33].

Carbon sequestration changes are not only related to global climate change, but also restrict the changes of other ecosystem functions closely related to human beings. Scholars use advanced methods and techniques to estimate the carbon sequestration potential of soil and vegetation pools in terrestrial ecosystems at various scales. In this study, the carbon sequestration of different land use types was estimated from 1986 to 2015 and the impact of mining activities and land reclamation on the dynamic changes of carbon sequestration in opencast mining areas of the Loess Plateau were analyzed. Finally, this paper presents a discussion on the impact of mining activities, vegetation types and soil quality 
on carbon sequestration, as well as the significance of carbon sequestration on land use. The purpose of this study is to propose a new perspective to guide future land use in mining areas and provides some references for policy relating to regional sustainable development.

\section{Material and Methods}

\subsection{Study Area}

Shuozhou, located in northwestern Shanxi Province, is a typical mining city in China. Pingshuo, one of the largest opencast coal mines in China, is located in northern Shanxi Province, east of the Loess Plateau $\left(112^{\circ} 10-113^{\circ} 30^{\prime} \mathrm{E}, 39^{\circ} 23^{\prime}-39^{\circ} 37^{\prime} \mathrm{N}\right.$; Figure 1). This area has a fragile ecology and experiences an arid to semi-arid continental monsoon climate, characterized by hot summers and dry, cold winters. The average annual precipitation is $428.2 \mathrm{~mm}$, the average annual temperature is $4.8-7.8^{\circ} \mathrm{C}$, the average annual wind speed is $2.5-4.2 \mathrm{~m} \cdot \mathrm{s}^{-1}$ and the maximum wind speed is $20 \mathrm{~m} \cdot \mathrm{s}^{-1}$. The zonal soils are chestnut calcareous and loess soils, which are of low soil organic content, poor structure, weak resistance and severe erosion.

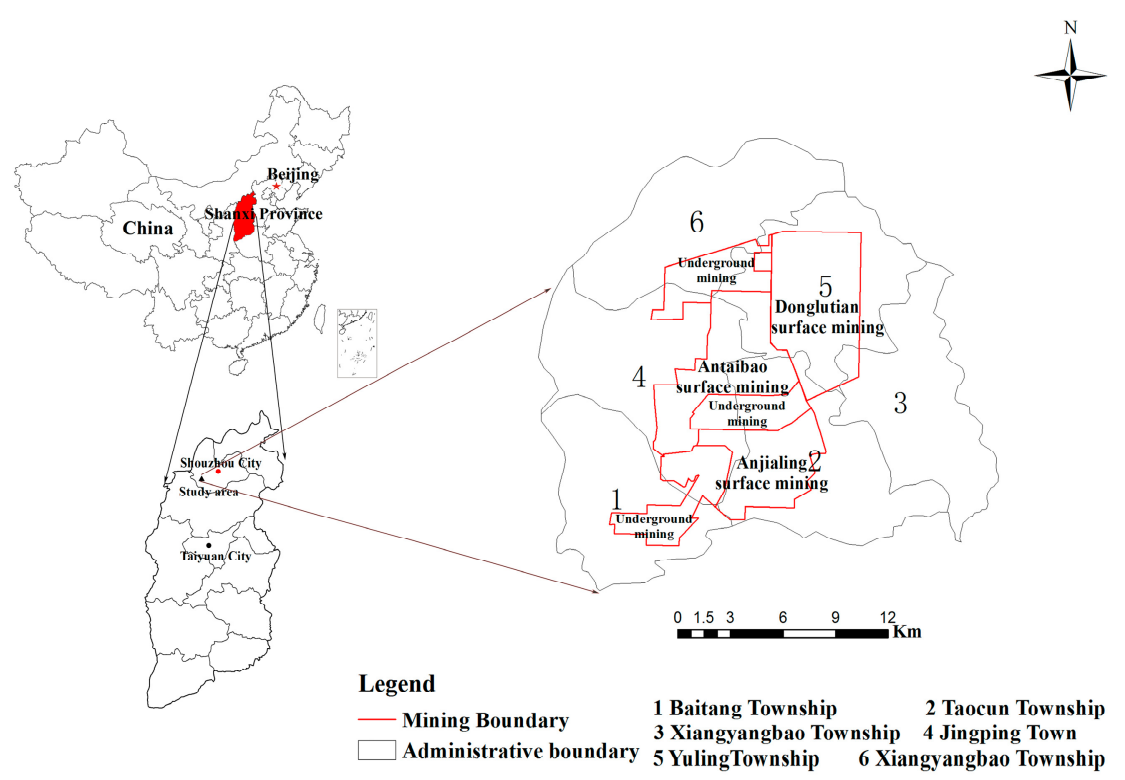

Figure 1. Location of the Pingshuo opencast coal mine in Shanxi Province, China.

The Pingshuo mining area covers a total area of $380 \mathrm{~km}^{2}$, in which three large-scale opencast mines are situated, representing an area of $179.37 \mathrm{~km}^{2}$. It has been proved that the geological reserves in Pingshuo mining area are up to 12.75 billion tons, regarding as the one of 14 large-scale coal production bases in China. The Pingshuo mining area consists six administrative towns, namely Jingping, Xiangyangbao, Baitang, Yuling, Taocun and Xiamiangao, as well as three opencast mines and three underground mines. This area has become the largest opencast mining area of 100 million tons, the largest coal gangue power generation base and a high-standard circular economy park with typical demonstration significance. The expanding scale of the coal mine has led to the relocation of rural settlements that have initiated new disturbance on land due to the construction of new rural areas. Mining activities; expansion of construction land; and relocation and resettlement of residential areas has led to changes in land use types.

In recent years, due to the implementation of the "grain for green" ecological policy, the area of arable land surrounding the mine has decreased while the area of woodland and grassland has increased. In 2015, the area of arable land was $6.32 \times 10^{4} \mathrm{hm}^{2}$, forestland was $2.35 \times 10^{4} \mathrm{hm}^{2}$, grassland was $1.67 \times 10^{4} \mathrm{hm}^{2}$ and damaged land was $5.93 \times 10^{4} \mathrm{hm}^{2}$, accounting for $37.92 \%, 14.07 \%, 10.11 \%$ and 
$35.56 \%$, respectively, of the total area. The rehabilitation area has been expanded at $200 \mathrm{hm}^{2}$ annually and has reached at total of $2600 \mathrm{hm}^{2}$.

\subsection{Data Source}

In this study, remote sensing images from 1986, 1996, 2000, 2004, 2009 and 2015 were used as data sources. Table 1 shows their parameters $(3 \mathrm{D}=$ three dimensional; $\mathrm{HRG}=$ high resolution graphic; HRS $=$ high resolution spectrometer; $\mathrm{TM}=$ thematic mapper). To obtain land use data of this area, the image was preprocessed in ENVI 4.8, including geometric correction (spatial reference is GSC_WGS_1984), atmospheric correction, radiometric correction, cropping and splicing. The Bayesian supervised classification method was adopted to select the region of interest, determine the sample for classification, and perform accuracy tests and corrections on the classified data. In order to ensure the reliability of image classification results, 60 patches were selected by sampling survey, of which 52 patches were consistent with the actual classification results, and the qualified rate was $86.67 \%$. A minimum Kappa coefficient value of 0.85 was selected as the critical value. When the kappa coefficient was calculated to be less than the critical value, the result was considered not credible and the sample was selected for reclassification. According to the comparison between the field research and remote sensing images of the mining area, the land use types of the mining area were divided into the following 10 types: arable land, forestland, grassland, urban land, rural land, transportation land, open-pit, stripping land, dump and industrial land. Table 2 describes in detail the classification of land use in mining areas.

Table 1. Parameters of remote sensing image.

\begin{tabular}{cccc}
\hline Number & Satellite(Sensor) & Date & Spatial Resolution(m) \\
\hline 1 & Landsat-5(TM) & 20 June 1986 & 30 \\
2 & Landsat-5(TM) & 25 June 1996 & 30 \\
3 & Landsat-5(TM) & 22 May 2000 & 30 \\
4 & SPORT-5 (HRG, HRS) & 16 May 2004 & 10 \\
5 & SPORT-5 (HRG, HRS) & 10 June 2009 & 10 \\
6 & SPORT-6(Reference 3D) & 1 July 2015 & 6 \\
\hline
\end{tabular}

Table 2. Land use classification of opencast coal mine based on remote sensing images.

\begin{tabular}{|c|c|}
\hline Land Use Type & Describing \\
\hline $\begin{array}{l}\text { Arable land } \\
\text { Grassland }\end{array}$ & $\begin{array}{l}\text { It refers to land that engages in agricultural activities to obtain food and products. } \\
\text { It refers to the land where the herbaceous plants are grown. }\end{array}$ \\
\hline Forestland & $\begin{array}{l}\text { It includes the original forest land in the study area and the dump site that has been } \\
\text { reclaimed as forest land. }\end{array}$ \\
\hline Urban land & It refers to the land for factories, houses, and parks in the city. \\
\hline Rural land & It mainly refers to the land of the rural residence base. \\
\hline Transportation land & It refers to land types such as ground lines and stations used for transportation. \\
\hline Stripping land & $\begin{array}{l}\text { It refers to the area formed by peeling off the topsoil and rock covering the ore body. } \\
\text { It refers to the mining operation, the original landform is continuously cut in the }\end{array}$ \\
\hline Opencast & $\begin{array}{l}\text { vertical direction and the horizontal direction, and finally a large pit of hundreds of } \\
\text { meters to several kilometers is formed. }\end{array}$ \\
\hline Dump & It refers to the large piles formed by the waste generated during the mining process. \\
\hline Industrial land & $\begin{array}{l}\text { It refers to the ground buildings, structures and related facilities that serve the mine } \\
\text { production system and auxiliary production systems. }\end{array}$ \\
\hline
\end{tabular}

The remote sensing images of the Pingshuo mining area from 1986, 1996 and 2000 were collected by Landsat 5 Thematic Mapper (TM) [34]. The remote sensing images from 2004, 2009 and 2015 were collected by SPORT-5. Although there are differences in resolution between the TM and SPORT images, there was no significant impact on the image classification results. First, the six images were separately interpreted. Each of the remote sensing images were interpreted independent of each other and had no effect on each other. Secondly, before processing of the remote sensing image data, we conducted a 
field investigation of the Pingshuo mining area to have a better understanding of the land use situation in the study area. Finally, Google Earth software was used as a reference during image processing to ensure the accuracy of land use information in the same location.

\subsection{Methods}

In this paper, we calculate vegetation and soil carbon sequestration. The soil data sampled from mining area cannot cover the whole research area, so this paper uses the previous research results in this area. The average soil carbon density of the arable land was $82.11 \mathrm{t} / \mathrm{hm}^{2}$, the forestland was $92.67 \mathrm{t} / \mathrm{hm}^{2}$ and the grassland was $88.35 \mathrm{t} / \mathrm{hm}^{2}[35,36]$, using the following equations:

$$
\begin{gathered}
P_{C}=C_{\text {soil }}+C_{\text {vegetation }} \\
C_{\text {soil }}=\sum_{i=1}^{n}\left(D_{i} \times A_{i}\right) \\
C_{\text {vegetation }}=C_{\text {forestland }}+C_{\text {grassland }}+C_{\text {arable-land }}
\end{gathered}
$$

where $P_{C}$ is the total carbon sequestration in $\mathrm{t} ; C_{\text {soil }}$ is the soil carbon sequestration in $\mathrm{t}$; $C_{\text {vegetation }}$ is the vegetation carbon sequestration in $\mathrm{t} ; D_{i}$ is the average soil carbon density of the land use type (i) in $\mathrm{t} / \mathrm{hm}^{2} ; A_{i}$ is the area of the land use type in $\mathrm{hm}^{2} ; C_{\text {forestland }}$ is the forestland carbon sequestration in $\mathrm{t}$; $C_{\text {grassland }}$ is the grassland carbon sequestration in $\mathrm{t}$; and $C_{\text {arable-land }}$ is the arable land carbon sequestration in $\mathrm{t}$.

The average vegetation carbon density of the forestland was $15.51 \mathrm{t} / \mathrm{hm}^{2}$ and the grassland carbon sequestration was calculated using the biomass density method. The average carbon density of the grassland refers to the survey data and research results in northern prairies of China [37-39].

$$
\begin{gathered}
C_{\text {forestland }}=D_{\text {forestland }} \times A_{i} \\
C_{\text {forestland }}=D_{\text {forestland }} \times A_{i} \\
C_{\text {arable-land }}=V p \times C_{\text {crop- }-i} \\
V p=Y_{\text {eco- } i} \times\left(1-P_{\text {water }-i}\right) \div H_{\text {crop }-i}
\end{gathered}
$$

where $V p$ is arable land biomass; $C_{c r o p-i}$ is the carbon sequestration coefficient of the crops; $Y_{\text {eco- } i}$ is the economic output; $P_{\text {water }-i}$ is average moisture content of the crops; and $H_{c r o p-i}$ is the economic coefficient.

The main calculation parameters of the arable land biomass in the study area are shown in Table 3. The data of average moisture content, economic coefficient and carbon storage coefficient comes from the results of related paper [40]. The economic output of various crops was mainly obtained through National Economic and Social Development Statistics (Statistical bureau of Shuozhou City, 1986, 1996, 2000, 2004, 2009 and 2015). Figure 2 shows a flowchart of the whole procedure.

Table 3. Biomass estimation parameters and carbon storage coefficients of different crops.

\begin{tabular}{cccc}
\hline Crop Type & Average Moisture Content & Economic Coefficient & Carbon Storage Coefficient \\
\hline Millet & 0.1375 & 0.40 & 0.4500 \\
Oats & 0.1250 & 0.40 & 0.4853 \\
Corn & 0.1350 & 0.40 & 0.4709 \\
Buckwheat & 0.1330 & 0.40 & 0.4853 \\
Soybean & 0.1250 & 0.35 & 0.4500 \\
Potato & 0.1330 & 0.70 & 0.4226 \\
Flax & 0.1330 & 0.39 & 0.4500 \\
Sunflower seed & 0.0900 & 0.30 & 0.4500 \\
\hline
\end{tabular}




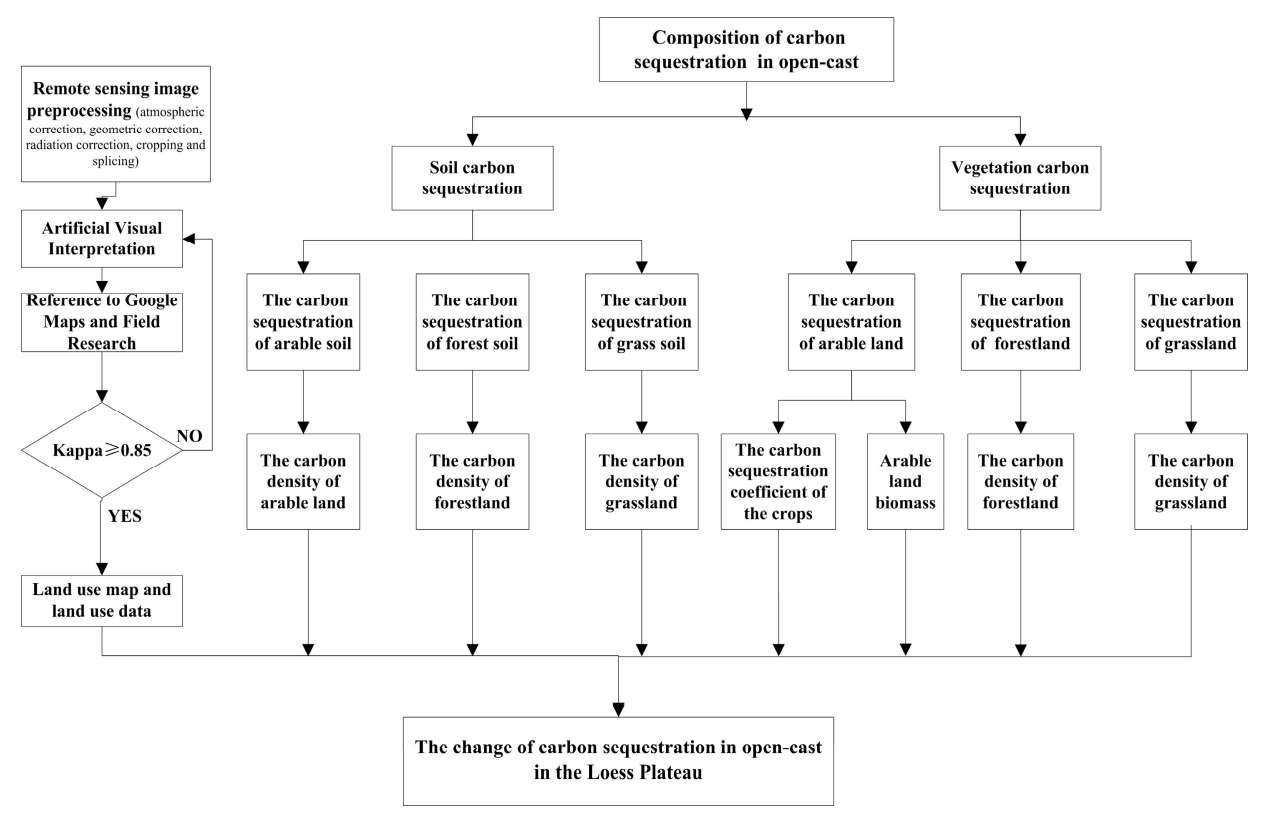

Figure 2. Flowchart of the whole procedure.

\section{Result and Analysis}

\subsection{Soil Carbon Sequestration}

Soil carbon sequestration showed a clear downward trend, decreasing from $4.36 \times 10^{6} \mathrm{Mg}$ in 1986 to $3.56 \times 10^{6} \mathrm{Mg}$ in 2015, which is an $18.35 \%$ reduction (Figure 3). Soil carbon sequestration is determined by the area of each land-use type and its average soil carbon density. When the average soil carbon density of all the regions is the same, the reduction of the land use types with higher average soil carbon densities (arable land and forestland) will lead to a decrease of soil carbon sequestration. In fact, the arable land and forestland in the study area significantly decreased from 1986 to 2015. Therefore, at the land use level, the reduction of arable land and forest for the past 30 years is the fundamental reason for the decreased total carbon sequestration in the study area.

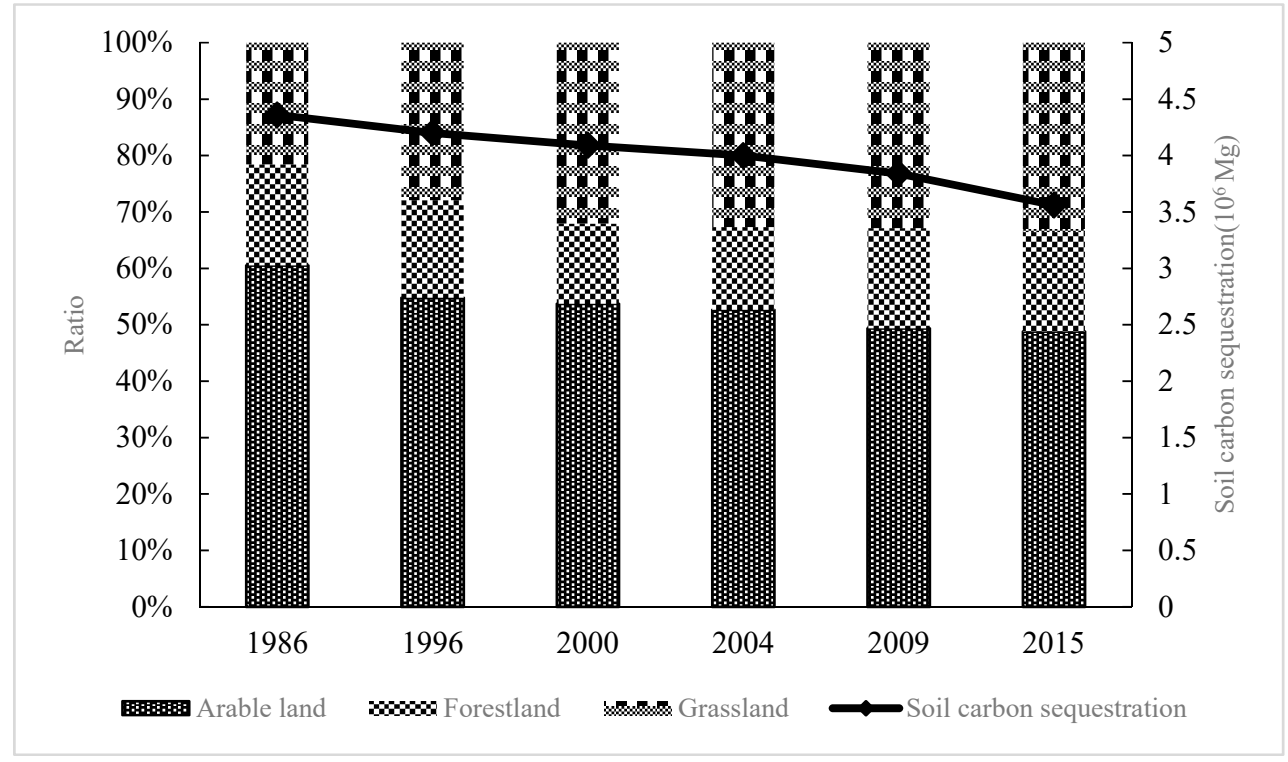

Figure 3. Change in soil carbon sequestration from 1986 to 2015. 
Arable land, forestland and grassland are important components of soil carbon sequestration in mining areas. The proportion of carbon sequestration in arable land was relatively large, at above $50 \%$, but it also showed a yearly decreasing trend. The carbon sequestration of grassland soil showed increase and then stabilized. The carbon sequestration of forestland showed an obvious fluctuation but accounted for a relatively small proportion. Table 4 shows dynamic land use changes in the Pingshuo opencast coal mine area. The Loess Plateau is an ecologically fragile area and is a key area for GGP in China. At the same time, Shanxi Province is a large coal-producing province in China, with coal mining also occupying a large amount of arable land. Between 1986 and 2015, the original landscape experienced serious damage in the Pingshuo mining area. A large number of high-carbon land use types, such as arable land, forestland and grassland have been converted into "high-emission" land use types, such as open-pit mining, dumping and industrial land. Of the arable land, $713.15 \mathrm{hm}^{2}$ was converted into open-pit mining, $838.2 \mathrm{hm}^{2}$ was converted into stripping land, $1494.66 \mathrm{hm}^{2}$ was converted into dumping and $711.76 \mathrm{hm}^{2}$ was converted into industrial land. Thus, land damage caused by mining has led to a significant reduction in soil carbon sequestration; however, land reclamation repaired the damaged land of mining disturbances and reconstructed the ecosystem of the mining area.

Table 4. Land use change in the Pingshuo opencast coal mine area from 1986 to 2015.

\begin{tabular}{|c|c|c|c|c|c|c|}
\hline \multirow{2}{*}{ Land Use Type } & \multicolumn{2}{|c|}{1986} & \multicolumn{2}{|c|}{1996} & \multicolumn{2}{|c|}{2000} \\
\hline & Area $/ \mathrm{hm}^{2}$ & Proportion & Area $/ \mathrm{hm}^{2}$ & Proportion & Area $/ \mathrm{hm}^{2}$ & Proportion \\
\hline Arable land & $32,119.68$ & $62.07 \%$ & $27,944.54$ & $54.00 \%$ & $26,746.18$ & $51.69 \%$ \\
\hline Forestland & 8426.73 & $16.28 \%$ & 7814.36 & $15.10 \%$ & 6286.87 & $12.15 \%$ \\
\hline Grassland & $10,655.54$ & $20.59 \%$ & $13,239.54$ & $25.58 \%$ & $14,840.15$ & $28.68 \%$ \\
\hline Urban land & 174.21 & $0.34 \%$ & 484.42 & $0.94 \%$ & 563.74 & $1.09 \%$ \\
\hline Rural land & 157.04 & $0.30 \%$ & 586.27 & $1.13 \%$ & 786.29 & $1.52 \%$ \\
\hline Transportation land & 214.85 & $0.42 \%$ & 390.95 & $0.76 \%$ & 399 & $0.77 \%$ \\
\hline Open pit & 0 & $0.00 \%$ & 278.46 & $0.54 \%$ & 535.08 & $1.03 \%$ \\
\hline Stripping land & 0 & $0.00 \%$ & 207.91 & $0.40 \%$ & 592.59 & $1.15 \%$ \\
\hline Dump & 0 & $0.00 \%$ & 590.84 & $1.14 \%$ & 594.26 & $1.15 \%$ \\
\hline Industrial land & 0 & $0.00 \%$ & 210.76 & $0.41 \%$ & 403.89 & $0.78 \%$ \\
\hline \multirow{2}{*}{ Land use type } & \multicolumn{2}{|c|}{2004} & \multicolumn{2}{|c|}{2009} & \multicolumn{2}{|c|}{2015} \\
\hline & Area $/ \mathrm{hm}^{2}$ & Proportion & Area $/ \mathrm{hm}^{2}$ & Proportion & Area $/ \mathrm{hm}^{2}$ & Proportion \\
\hline Arable land & $25,619.87$ & $49.51 \%$ & $23,077.10$ & $44.60 \%$ & $21,186.63$ & $40.94 \%$ \\
\hline Forestland & 6333.93 & $12.24 \%$ & 7372.44 & $14.25 \%$ & 6775.52 & $13.09 \%$ \\
\hline Grassland & $14,789.41$ & $28.58 \%$ & $14,285.11$ & $27.61 \%$ & $13,551.70$ & $26.19 \%$ \\
\hline Urban land & 720.20 & $1.39 \%$ & 923.08 & $1.78 \%$ & 1169.40 & $2.26 \%$ \\
\hline Rural land & 928.11 & $1.79 \%$ & 1350.46 & $2.61 \%$ & 1677.88 & $3.24 \%$ \\
\hline Transportation land & 407.87 & $0.79 \%$ & 419.80 & $0.81 \%$ & 552.86 & $1.07 \%$ \\
\hline Open pit & 886.52 & $1.71 \%$ & 848.68 & $1.64 \%$ & 1390.31 & $2.69 \%$ \\
\hline Stripping land & 649.98 & $1.26 \%$ & 1035.25 & $2.00 \%$ & 1367.69 & $2.64 \%$ \\
\hline Dump & 720.01 & $1.39 \%$ & 1578.20 & $3.05 \%$ & 2662.27 & $5.14 \%$ \\
\hline Industrial land & 692.15 & $1.34 \%$ & 857.93 & $1.66 \%$ & 1200.81 & $2.32 \%$ \\
\hline
\end{tabular}

\subsection{Vegetation Carbon Sequestration}

From 1986 to 2015, vegetation carbon sequestration fluctuated; however, the range was relatively small (Figure 4). The carbon sequestration of the forestland first decreased, then increased and finally decreased. The increase of forestland carbon sequestration in 2009 was mainly due to the vigorous implementation of the GGP policy and the reclamation of the dumps in the mining areas. After the Donglutian opencast coal mine became operational in 2009, the carbon sequestration of the forestlands decreased. Grassland carbon sequestration first increased and then decreased. Soil erosion in the Loess Plateau is serious, resulting in the change of peasant production mode.

Owing to the fragile ecology, serious soil erosion and 428.2-mm annual rainfall in the Loess Plateau, the main crops that are planted are millet, oat, corn, buckwheat, soybean, potato, flax and sunflower. Crops are an important source of carbon sequestration on arable land. Over the last 30 years, the ratio of oats grown in the Loess Plateau has decreased yearly. By 1986, oats and potatoes were 
given priority; in 2015, this changed to include corn, buckwheat and potato crop production. Carbon sequestration in the arable land first decreased and then increased (Figure 5). The reason for this is that a large amount of arable land was invaded due to rapid population growth and serious expansion of construction land in this region.

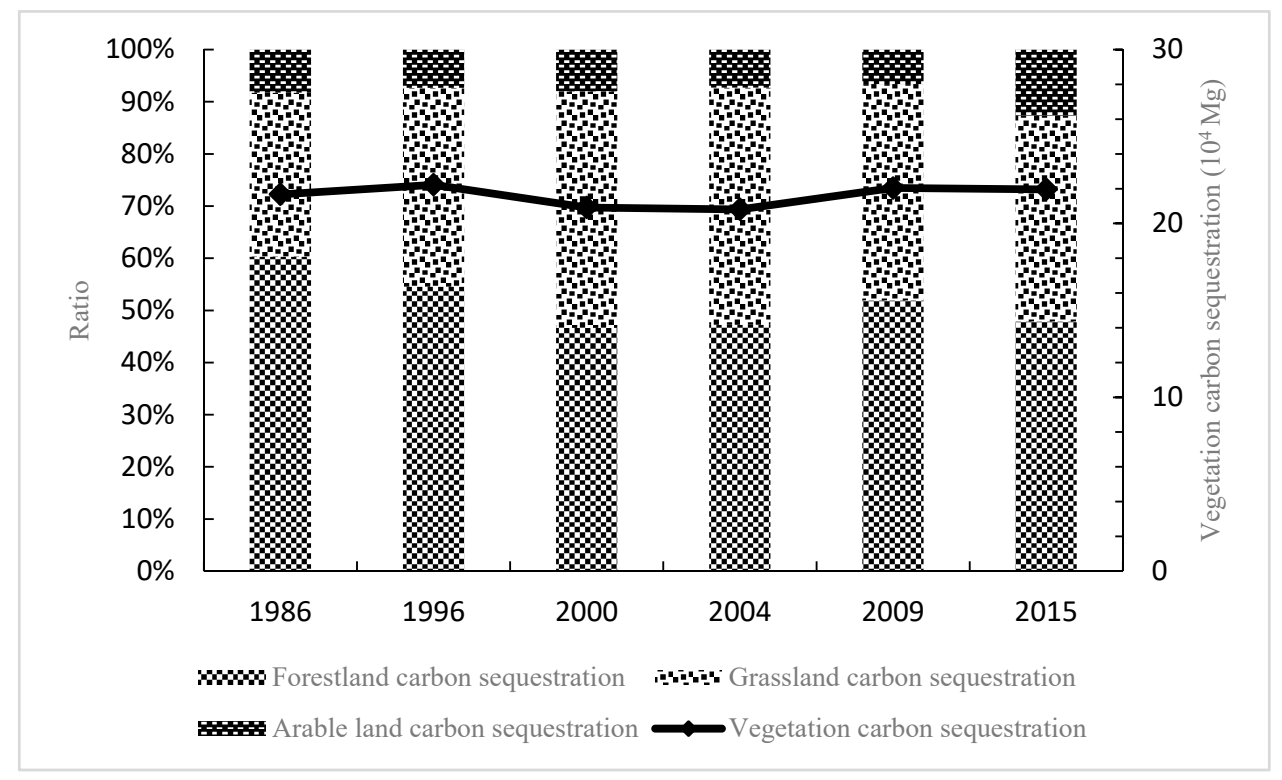

Figure 4. Change in vegetation carbon sequestration from 1986 to 2015.

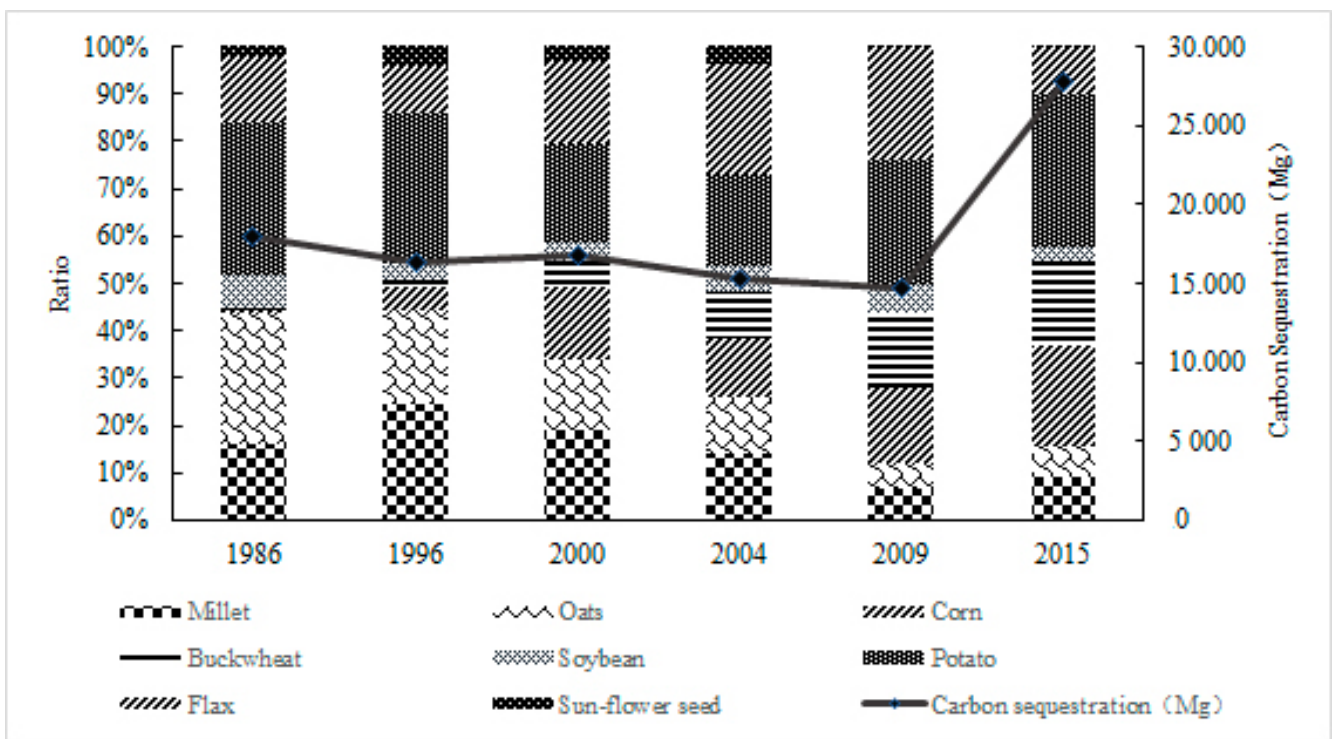

Figure 5. Change in arable land vegetation carbon sequestration from 1986 to 2015.

In 2001, the An-taibao opencast coal mine became operational. Mining activities results in the reduction of arable land and crop area, which in turn leads to the decline of carbon sequestration in arable land. After 2009, there was a sharp increase in the carbon sequestration of arable land. By 2015, the total carbon sequestration was $2.78 \times 10^{4} \mathrm{Mg}$. This is because, after long-term land reclamation, a large amount of arable land became cultivable.

\subsection{The Total Carbon Sequestration}

The variation in carbon sequestration of different land use types and the total carbon sequestration is shown in Figure 6. In the past 30 years, the total carbon sequestration of the Pingshuo mining 
area has shown a significant downward trend from $4.58 \times 10^{6} \mathrm{Mg}$ in 1986 to $3.78 \times 10^{6} \mathrm{Mg}$ in 2015 . The proportion of carbon sequestration in arable land was large, showing a significant downward trend, while that of grassland showed an increasing trend from 1986 to 2000. However, with the continuous expansion of mining operations, carbon sequestration from grassland showed a downward trend after 2000. Forestland carbon sequestration showed a decreasing trend from 1986 to 2000. After 2000, the carbon sequestration in the forestland showed an upward trend, which was mainly due to implementation of the GGP and reclaiming of forestland in mining areas.

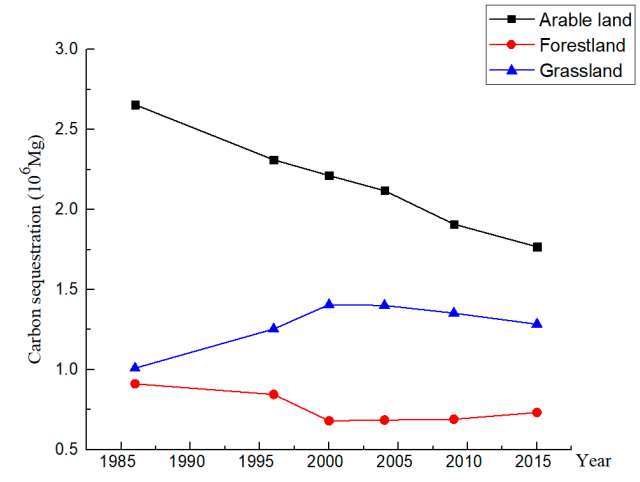

a

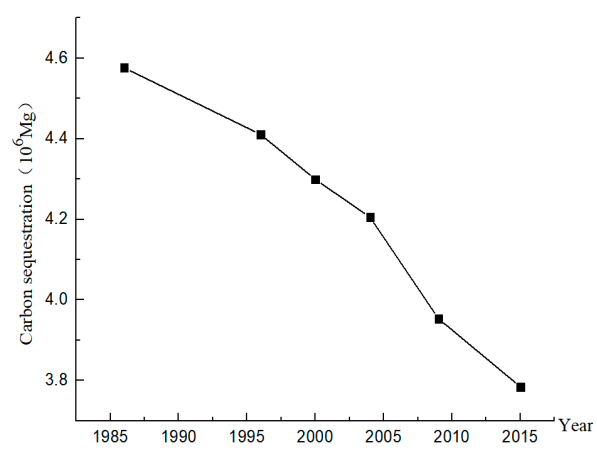

$\mathrm{b}$

Figure 6. Change in carbon sequestration from 1986 to 2015. (a) Change of carbon sequestration in arable land, forestland and grassland. (b). Change of total carbon sequestration in Pingshuo mining area.

The essence of land reclamation is the process of restoring the natural ecosystem of a disturbed area. It is an environment consisting of mountains, water, forests, farmland, lakes and grassland. In the process of reclamation, the characteristics of the natural environment in the region need to be considered so as to improve land productivity and maximize its ecological function. Finally, a low-carbon layout with high efficiency and low energy consumption can be formed.

The rationality of land use structure determines the function of the land in the region. In order to prevent and control various disasters and risks, the concept of sustainable, multi-functional and diversified land use should be considered. To select and design appropriate reclamation techniques (including biological and engineering measures) during land reclamation of the mine area, we should reclaim the damaged areas to high-carbon land use types, such as forestland, grassland and farmland. This is crucial for increasing carbon storage in the mining area. In order to achieve the goal of ecological agriculture, the soil in the mining area needs to be improved and the land productivity per unit area needs to be increased. If we simply focus on the cultivation of early vegetation, but neglect conservation and management in the later stage, it will be very difficult for ecological restoration to play an important and sustainable role. Therefore, we need to pay attention to post-reclamation management. Thus, the supervision and maintenance of reclamation projects are very important for improving the sustainability of ecological reclamation work and creating long-term ecological value.

\section{Discussion}

\subsection{The Impact of Mining Activities on Carbon Sequestration}

Carbon sequestration capacities differ between different ecosystems. Human activities and coal mining have led to changes in land use types that result in carbon fixation losses [1]. China is not only an important coal producer but also a coal-consuming country. By 2015, China had identified 1566.3 billion tons of coal reserves. The provinces with the top five recoverable reserves in China are Shanxi, Neimeng, Shaanxi, Xinjiang and Guizhou, accounting for 37.76\%, 20.20\%, 6.49\%, 5.19\% and $4.17 \%$, respectively. The advantages of large productivity, low mining costs, high recycling rates and high safety are the basis for rapid development of opencast coal mines. There are many mining 
areas in China that are similar to the Pingshuo mining area. Furthermore, across the country, there are 14 major super-large opencast mines, 27 large opencast mines and 11 medium-sized opencast mines. Science-based land reclamation and ecological restoration can improve the function of carbon sinks and increase the biodiversity of mining areas. Mining area, as a complex community involving natural, social and economic factors, require supervision at the later stage of land reclamation to prevent soil degradation caused by overgrazing and improper cultivation management and to achieve sustainable development [41,42].

$\mathbf{A}$

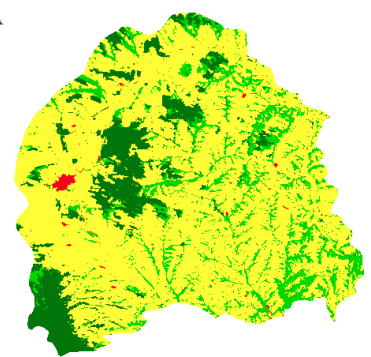

1986

C

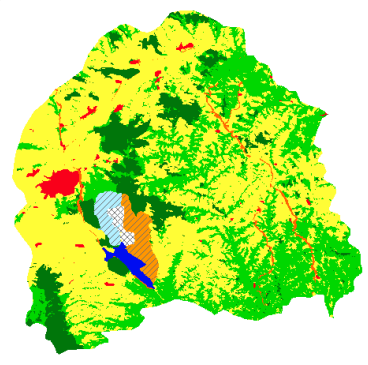

2000

E

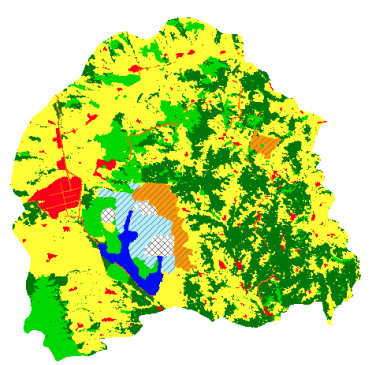

2009

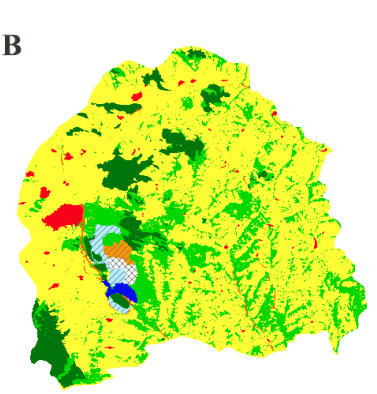

1996

D

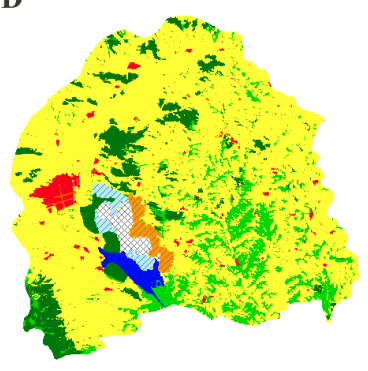

2004

F

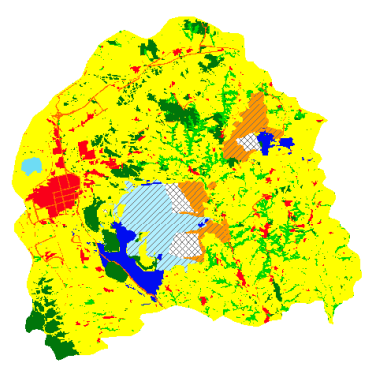

2015

Legend

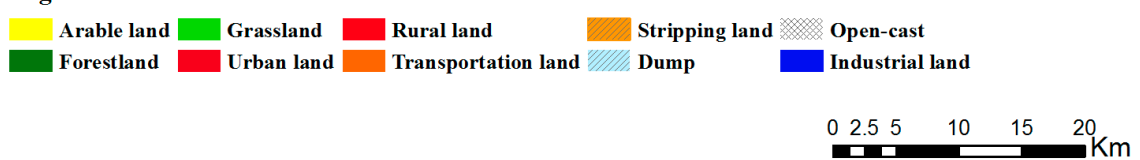

Figure 7. Land use type of Pingshuo opencast coal mine in 1986, 1996, 2000, 2004, 2009 and 2015. (A) Land use type of Pingshuo mining area in 1986. (B) Land use type of Pingshuo mining area in 1996.

(C) Land use type of Pingshuo mining area in 2000 (D) Land use type of Pingshuo mining area in 2004.

(E) Land use type of Pingshuo mining area in 2009. (F) Land use type of Pingshuo mining area in 2015. 
By analyzing remote sensing images of the mining area from 1986, 1996, 2000, 2004, 2009 and 2015, we obtained data on land use changes in the study area. We found that the types of land use changed significantly during the 30-year study period and that the land use structure has been dominated by arable land, forestland and grassland (Figure 7).

New types of land use have emerged and grown increasingly fast during the study period, such as open-pit mining, stripping, un-reclamation dumping, industrial sites and other types of damaged land. The An-taibao opencast coal mine, which was the main site between 1986 and 2000, had a had a damaged area of $1995.79 \mathrm{hm}^{2}$ and a damaged-land growth rate of $142 \mathrm{hm}^{2} / \mathrm{a}$. The An-jialing and the Donglutian opencast coal mines were successively put into production from 2001 to 2011. As of 2015, the open pit area reached $1062.70 \mathrm{hm}^{2}$, accounting for $6.38 \%$ of the total area, and the un-reclamation dump site reached $2594.41 \mathrm{hm}^{2}(15.56 \%)$. In 2015 , the total area of land damage in the Pingshuo mining area reached $5297.13 \mathrm{hm}^{2}(35.56 \%)$ and the growth rate of damaged land was $1.23 \% / \mathrm{a}$. Land use change shows the same trend as vegetation and soil carbon sequestration change in the Pingshuo mining area. The specific land use changes in the Pingshuo opencast coal mine area is shown in Figure 8.

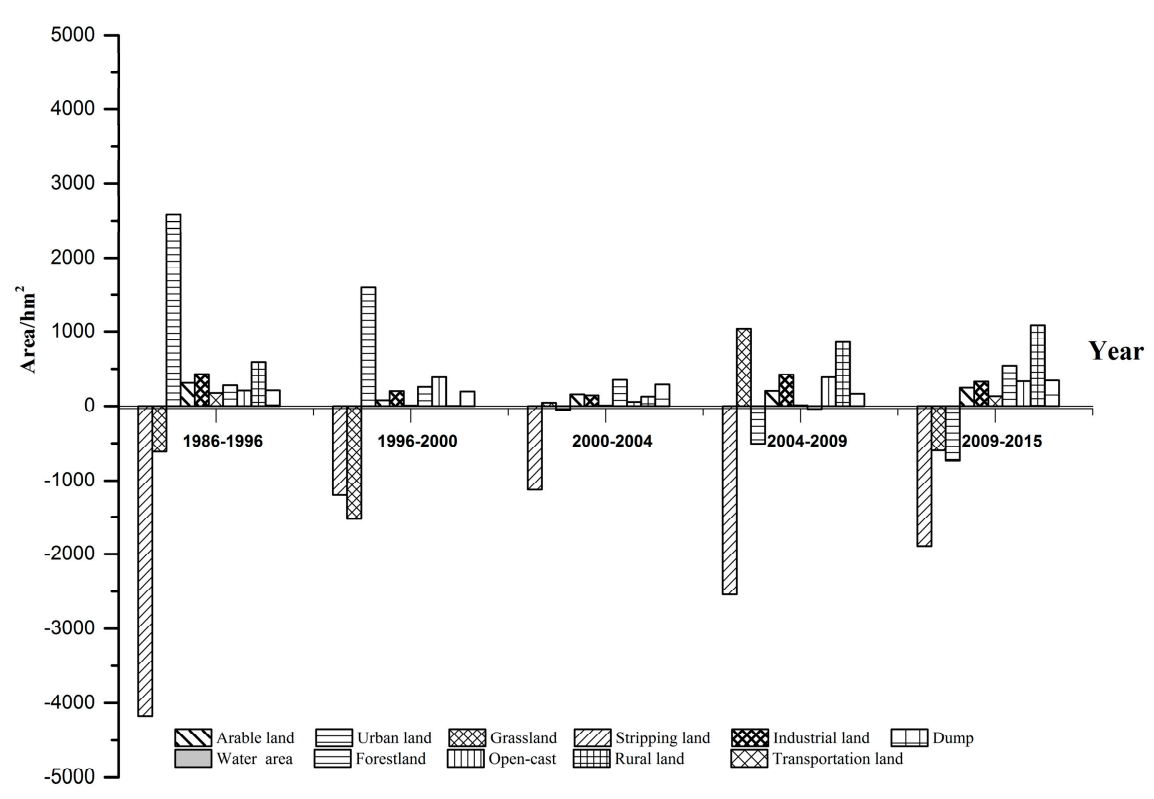

Figure 8. Dynamic land use change in the Pingshuo opencast coal mine area.

Vegetation and soil can better absorb atmospheric carbon dioxide [4]. At the same time, carbon sequestration occurs in soil and vegetation and is highly sensitive to land use changes. Studies have shown that when marshlands are converted to arable land, its contribution to global warming mitigation will be lower than that of the original marshlands [43]. The future carbon sequestration potential of the Grain for Green Program (GGP) in Henan Province is estimated based on empirical growth curves and various parameters, with the carbon sink increment expected to reach $136.97 \mathrm{Tg}$ by 2050 [29]. The GGP increased SOC storage by $9.03 \mathrm{MgCha}(-1)$ on average [44].

Although the Chinese government emphasizes the importance of the GGP, due to the pressure of the farmland redline and food security, it is currently only possible to implement farmland conversion in ecologically fragile and large sloped areas. In addition, open-pit mining in mining areas causes substantial agricultural land damage, further reducing carbon sequestration. In comparison, laws and policies are more strictly adhered to in the developed world [45]. During the process of reclamation, the balance of cultivated land occupation and compensation is also emphasized, which hinders the restoration of forestland and grassland. Thus, for large carbon emitters in the mining industry, the pressure for carbon emission reduction and carbon sequestration is still relatively large. 


\subsection{The Impact of Vegetation Type and Soil Quality on Carbon Sequestration}

Land use management strategies play a decisive role in soil carbon storage [46]. According to studies, perennial vegetation can reduce the loss of organic carbon when mining activities destroy the natural vegetation [47]. SOC sequestration varies with age and land use type. Furthermore, the carbon sequestration capacity of topsoil is stronger than that of deep soil. In the Loess Plateau, shrublands have better long-term carbon sequestration than natural grasslands and woodlands [48]. Thus, the type of vegetation should be carefully considered during vegetation selection for land reclamation. In areas with low initial SOC, especially in semiarid environments, the SOC storage in ex-arable land is relatively strong [23]. The implementation of land reclamation has increased the SOC storage of degraded lands and disturbances caused by mining activities [49,50]. The lack of SOC in mining areas mainly comes from carbon sequestration of reclaimed soil and vegetation [3]. Improvement of soil quality and selection of suitable vegetation in reclaimed land plays an important role in enhancing the carbon sequestration potential in mining areas. Soil organic matter in the early stage of the reclamation process is very important for the recovery of SOC in the late stage of mining and the carbon sequestration capacity will be strengthened over time [51,52].

The Chinese government focuses on the establishment of agricultural ecosystems with a low-carbon cycle. Thus, the re-establishment of agricultural production in mining areas should emphasize low-carbon farming methods. Farmers need to apply organic fertilizers while reducing the use of chemical fertilizers and pesticides during the planting of crops. This method helps to increase the content of SOC. Farmers may be able to use straw and conservation tillage practices to increase soil carbon storage and soil carbon sequestration. The destroyed land can be till age; loose topsoil; deep plowing improved soil imperfections (such as plow bottom layer, clay layer, ginger layer or pebble layer), to eliminate barriers of plant growth and to ultimately become a quality soil.

Forestland plays an important role in improving the carbon cycle and in climate regulation of mining ecosystems. With respect to the carbon cycle of mining areas, the reclaimed vegetation forest carbon pool is important for the reclaimed ecosystem and could reach more than $50 \%$ of the total carbon pool of that ecosystem [26,27]. It has been shown that Picea, Pinus sylvestnisvar, Robiniapseudoacacia and Sophorajaponica are highly adaptable to pollutants discharged from mining activities and can effectively reduce carbon emissions [53].

\subsection{The Guiding Significance of Carbon Sequestration on Land Use}

Through the implementation of land reclamation projects, such as land remodeling, soil rebuilding and vegetation reconstruction, the mining ecosystem will be gradually transformed from a "carbon source" to a "carbon sink". The results show that there were 5.9127 million tons carbon emissions from the three large-scale opencast mines in Pingshuo during the study period. The total amount of carbon emissions generated by fuel use, self-dissemination, electricity production and blasting was approximately 3.02 million tons, 2.04 million tons, 0.69 million tons and 0.16 million tons, respectively [54]. The land reclamation project is a significant increase in the carbon sequestration of arable land vegetation after 2009 in China's Loess Plateau.

Landholders and policy makers need to understand the changes in carbon sequestration of mining areas and make decisions on future mining activities in order to ultimately reconstruct a technically feasible, economically viable and environmentally sustainable ecosystem [55]. During the opencast mining process, the stripping of topsoil is decreased, the original geomorphic disturbance area is reduced and large carbon loss is avoided. At the same time, the mining area reduces the degree of disturbance and scope of land resources during coal mining through corresponding technical measures and it fully exploits the production potential of land resources and achieves "stripping-mining activities-transport-disposal-land reclamation" integration [56].

For the process of coal mining, we must establish a goal of expanding energy conservation implementation, consumption reduction and emission reduction projects in order to develop a circular economy. According to mineral resource burial and development timing, a series of measures should 
be taken to reduce the impact of coal mining on the ecological environment. The mining area should recover the washed coal slime and use the coal gangue to generate electricity. The fly ash produced after power generation can be used to extract alumina and other rare metals. For the district to collect heat, slag and other waste materials should be used to make wall materials. Finally, the mining of resources in the area should be refined, waste utilization should be maximized and environmental pollution should be minimized.

The damaged land in the mining area should be preferentially reclaimed as cultivable land, forestland and grassland that has a strong carbon sequestration capacity. In various ways, the carbon sequestration capacity of forestland, grassland and arable land reclaimed in the mining area can compensate for the large amount of carbon emissions generated by the mining operations. The quality of the soil in the mining area is related to the restoration effects of the reclaimed vegetation. The surface soil of the mining area should be discharged to the top $2 \mathrm{~m}$ of the dumping and the soil layer should not be compacted by heavy machinery. The slope inclination of the reclamation site in the mining area shout not generally be not more than 1:4 (25\%) to allow for mechanical tending and harvesting [57]. In the process of land reclamation, attention should be paid to the protection of the soil tillage layer. The selected plants should have strong adaptability and, preferably, a nitrogen fixation capacity (such as legumes). Furthermore, the root system should be developed with good growth rate and strong drought resistance. Finally, they should have a high survival rate and an ability to produce a large amount of organic waste, which increases humus and carbon sequestration in the soil.

\section{Conclusions}

1. In the past 30 years, from 1986 to 2015 , carbon sequestration decreased yearly, with the soil carbon storage accounting for a large proportion of this. After land reclamation and ecological restoration, the reduction of carbon sequestration began to slow down. Carbon sequestration in 1986, $1996,2000,2004,2009$ and 2015 was $4.58 \times 10^{6} \mathrm{Mg}, 4.41 \times 10^{6} \mathrm{Mg}, 4.30 \times 10^{6} \mathrm{Mg}, 4.21 \times 10^{6} \mathrm{Mg}$, $3.95 \times 10^{6} \mathrm{Mg}$ and $3.78 \times 10^{6} \mathrm{Mg}$, respectively.

2. During the 30-year study period, the total carbon sequestration of the mining area was $2.52 \times 10^{7} \mathrm{Mg}$. The arable land carbon reserves were $1.30 \times 10^{7} \mathrm{Mg}$, the forestland carbon sequestration was $4.55 \times 10^{6} \mathrm{t}$ and the grassland carbon storage was $7.71 \times 10^{6} \mathrm{Mg}$, accounting for $51 \%, 18 \%$ and $31 \%$, respectively, of the total carbon sequestration in the mining area. The change in total carbon sequestration of mining area had a significant negative correlation with the amount of coal mining.

3. In 2015, the area of damaged land in the Pingshuo mining area reached $5297.13 \mathrm{hm}^{2}$, accounting for $35.56 \%$ of the total area, and the growth rate of the damaged land was $1.23 \% / \mathrm{a}$. After implementation of engineering measures, such as land reclamation and ecological restoration of the damaged land, the carbon storage of arable land significantly increased from $1.79 \times 10^{4} \mathrm{Mg}$ in 1986 to $2.78 \times 10^{4} \mathrm{Mg}$ in 2015 with a growth rate of $35.7 \%$. This shows that performing science-based land reclamation is conducive to increasing the carbon sequestration capability of the mining area.

The soil data sampled from mining area cannot cover the whole research area, so this paper uses the previous research results in this area. This paper does not consider the effects of the tree root system, tree age, tree species on carbon sequestration. In the future, soil types and vegetation types will be further studied. At the same time, policy implementation will affect carbon sequestration changes in a certain extent (for example, the GGP in the Loess Plateau), the next research will further analyze the impact of policy on carbon sequestration. We are not using more recent remote sensing images (2018), because we want to analyze the changes in carbon sequestration in the 30 years from 1986 to 2015. In future studies, we may use updated remote sensing images to analyze carbon sequestration changes in longer time series.

Author Contributions: Z.B., Y.C. designed the research. B.Y., X.Z., F.X., J.Z. and Y.W. performed research and analyzed data. B.Y. draft the initial manuscript. Z.B., Y.C. revised and approved the manuscript. All authors gave final approval for publication. 
Funding: This research was supported by National Science Foundation of China (U1810107) (41701607) and the Basic Scientific Research Foundation for Excellent Supervisors (2-9-2018-025).

Acknowledgments: We also thank ChinaCoal Pingshuo Group for its strong support.

Conflicts of Interest: The authors declare no conflicts of interest.

\section{References}

1. Lai, L.; Huang, X.J.; Yang, H.; Chuai, X.W.; Zhang, M.; Zhong, T.Y.; Chen, Z.G.; Chen, Y.; Wang, X.; Thompson, J.R. Carbon emissions from land-use change and management in China between 1990 and 2010. Sci. Adv. 2016, 2, e1601063. [CrossRef] [PubMed]

2. Shao, S.; Liu, J.; Geng, Y.; Miao, Z.; Yang, Y. Uncovering driving factors of carbon emissions from China's mining sector. Appl. Energy 2016, 166, 220-238. [CrossRef]

3. Das, R.; Maiti, S.K. Importance of carbon fractionation for the estimation of carbon sequestration in reclaimed coalmine soils-A case study from Jharia coalfields, Jharkhand, India. Ecol. Eng. 2016, 90, 135-140. [CrossRef]

4. Pandey, V.C.; Sahu, N.; Behera, S.K.; Singh, N. Carbon sequestration in fly ash dumps: Comparative assessment of three plant association. Ecol. Eng. 2016, 95, 198-205. [CrossRef]

5. del Mar Montiel-Rozas, M.; Panettieri, M.; Madejón, P.; Madejón, E. Carbon Sequestration in Restored Soils by Applying Organic Amendments. Land Degrad. Dev. 2016, 27, 620-629. [CrossRef]

6. Lal, R.; Follett, R.F.; Kimble, J.M. Achieving Soil Carbon Sequestration in the United States: A Challenge to the Policy Makers. Soil Sci. 2003, 168, 827-845. [CrossRef]

7. Longmire, A.; Taylor, C.; Pearson, C.J. An open-access method for targeting revegetation based on potential for emissions reduction, carbon sequestration and opportunity cost. Land Use Policy 2015, 42, 578-585. [CrossRef]

8. Alberti, G.; Leronni, V.; Piazzi, M.; Petrella, F.; Mairota, P.; Peressotti, A.; Piussi, P.; Valentini, R.; Gristina, L.; La Mantia, T.; et al. Impact of woody encroachment on soil organic carbon and nitrogen in abandoned agricultural lands along a rainfall gradient in Italy. Reg Environ. Chang. 2011, 11, 917-924. [CrossRef]

9. La Mantia, J.; Klapste, J.; El-Kassaby, Y.A.; Azam, S.; Guy, R.D.; Douglas, C.J.; Mansfield, S.D.; Hamelin, R. Association Analysis Identifies Melampsora xcolumbiana Poplar Leaf Rust Resistance SNPs. PLoS ONE 2013, 8, e78423. [CrossRef] [PubMed]

10. Ruhl, A.S.; Zietzschmann, F.; Altmann, J.; Meinel, F.; Sperlich, A.; Jekel, M. Stratification of Granular Activated Carbon Filters for Advanced Wastewater Treatment. Water Air Soil Pollut. 2015, 226, 384. [CrossRef]

11. Van Eerd, L.L.; Congreves, K.A.; Hayes, A.; Verhallen, A.; Hooker, D.C. Long-term tillage and crop rotation effects on soil quality, organic carbon, and total nitrogen. Can. J. Soil Sci. 2014, 94, 303-315. [CrossRef]

12. Shrestha, R.K.; Lal, R. Soil carbon and nitrogen in 28-year-old land uses in reclaimed coal mine soils of Ohio. J. Environ. Qual 2007, 36, 1775-1783. [CrossRef] [PubMed]

13. Keesstra, S.D.; Geissen, V.; Mosse, K.; Piirainen, S.; Scudiero, E.; Leistra, M.; van Schaik, L. Soil as a filter for groundwater quality. Curr. Opin. Environ. Sustain. 2012, 4, 507-516. [CrossRef]

14. Brevik, I.; Obukhov, V.V.; Timoshkin, A.V. Dark energy coupled with dark matter in viscous fluid cosmology. Astrophys. Space Sci. 2015, 355, 399-403. [CrossRef]

15. Munoz-Rojas, M.; Jordan, A.; Zavala, L.M.; De la Rosa, D.; Abd-Elmabod, S.K.; Anaya-Romero, M. Organic carbon stocks in Mediterranean soil types under different land uses (Southern Spain). Solid Earth 2012, 3, 375-386. [CrossRef]

16. Barua, S.K.; Haque, S.M.S. Soil Characteristics and Carbon Sequestration Potentials of Vegetation in Degraded Hills of Chittagong, Bangladesh. Land Degrad. Dev. 2013, 24, 63-71. [CrossRef]

17. Bendfeldt, E.S.; Burger, J.A.; Daniels, W.L. Quality of amended mine soils after sixteen years. Soil Sci. Soc. Am. J. 2001, 65, 1736-1744. [CrossRef]

18. Lal, R. Crop residues as soil amendments and feedstock for bioethanol production. Waste Manag. 2008, 28, 747-758. [CrossRef] [PubMed]

19. Cortina, J.; Amat, B.; Castillo, V.; Fuentes, D.; Maestre, F.T.; Padilla, F.M.; Rojo, L. The restoration of vegetation cover in the semi-arid Iberian southeast. J. Arid. Environ. 2011, 75, 1377-1384. [CrossRef]

20. Munson, S.M.; Lauenroth, W.K. Plant Community Recovery Following Restoration in Semiarid Grasslands. Restor. Ecol 2012, 20, 656-663. [CrossRef] 
21. Chen, L.; Gong, J.; Fu, B.; Huang, Z.; Huang, Y.; Gui, L. Effect of land use conversion on soil organic carbon sequestration in the loess hilly area, loess plateau of China. Ecol. Res. 2006, 22, 641-648. [CrossRef]

22. Wang, B.; Zhang, G.H.; Shi, Y.Y.; Li, Z.W.; Shan, Z.J. Effects of Near Soil Surface Characteristics on the Soil Detachment Process in a Chronological Series of Vegetation Restoration. Soil Sci. Soc. Am. J. 2015, 79, 1213-1222. [CrossRef]

23. Kampf, I.; Holzel, N.; Storrle, M.; Broll, G.; Kiehl, K. Potential of temperate agricultural soils for carbon sequestration: A meta-analysis of land-use effects. Sci. Total Environ. 2016, 566, 428-435. [CrossRef] [PubMed]

24. Yuan, Y.; Zhao, Z.; Li, X.; Wang, Y.; Bai, Z. Characteristics of labile organic carbon fractions in reclaimed mine soils: Evidence from three reclaimed forests in the Pingshuo opencast coal mine, China. Sci. Total Environ. 2018, 613-614, 1196-1206. [CrossRef] [PubMed]

25. Yuan, Y.; Zhao, Z.; Bai, Z.; Wang, H.; Wang, Y.; Niu, S. Reclamation patterns vary carbon sequestration by trees and soils in an opencast coal mine, China. Catena 2016, 147, 404-410. [CrossRef]

26. Karu, H.; Szava-Kovats, R.; Pensa, M.; Kull, O. Carbon sequestration in a chronosequence of Scots pine stands in a reclaimed opencast oil shale mine. Can. J. For. Res. 2009, 39, 1507-1517. [CrossRef]

27. Shrestha, R.K.; Lal, R. Carbon and nitrogen pools in reclaimed land under forest and pasture ecosystems in Ohio, USA. Geoderma 2010, 157, 196-205. [CrossRef]

28. Frouz, J.; Pizl, V.; Cienciala, E.; Kalcik, J. Carbon storage in post-mining forest soil, the role of tree biomass and soil bioturbation. Biogeochemistry 2009, 94, 111-121. [CrossRef]

29. Wang, Y.F.; Liu, L.; Shangguan, Z.P. Carbon storage and carbon sequestration potential under the Grain for Green Program in Henan Province, China. Ecol. Eng. 2017, 100, 147-156. [CrossRef]

30. Amichev, B.Y.; Burger, J.A.; Rodrigue, J.A. Carbon sequestration by forests and soils on mined land in the Midwestern and Appalachian coalfields of the U.S. For. Ecol. Manag. 2008, 256, 1949-1959. [CrossRef]

31. Peters, G.P.; Andrew, R.M.; Boden, T.; Canadell, J.G.; Ciais, P.; Le Quere, C.; Marland, G.; Raupach, M.R.; Wilson, C. COMMENTARY: The challenge to keep global warming below 2 degrees C. Nat. Clim. Chang. 2013, 3, 4-6. [CrossRef]

32. Ussiri, D.A.N.; Lal, R. Carbon sequestration in reclaimed minesoils. Crit. Rev. Plant Sci. 2005, 24, $151-165$. [CrossRef]

33. Bai, Z.; Zhao, J.; Li, J.; Wang, W.; Lu, C.; Ding, X.; Chai, S.; Chen, J.J. Ecosystem damage in a large opencast coal mine-a case study on Pingshuo surface coal mine, China. Acta Ecol. Sin. 1999, 6, 870-875.

34. Liu, K.L.; Wang, J.D.; Zeng, W.S.; Song, J.L. Comparison and Evaluation of Three Methods for Estimating Forest above Ground Biomass Using TM and GLAS Data. Remote Sens. 2017, 9, 341. [CrossRef]

35. Li, K.R.; Wang, S.Q.; Cao, M.Q. Chinese vegetation and soil carbon storage. Sci. China 2003, 33, 72-80.

36. Wang, J.M.; Jiao, Z.Z.; Bai, Z.K. Changes in carbon sink value based on RS and GIS in the Heidaigou opencast coal mine. Environ. Earth Sci. 2014, 71, 863-871. [CrossRef]

37. Piao, S.L.; Fang, J.Y.; Zhou, L.M.; Tan, K.; Tao, S. Changes in biomass carbon stocks in China's grasslands between 1982 and 1999. Glob. Biogeochem. Cycles 2007, 21. [CrossRef]

38. Fan, J.W.; Zhong, H.P.; Harris, W.; Yu, G.R.; Wang, S.Q.; Hu, Z.M.; Yue, Y.Z. Carbon storage in the grasslands of China based on field measurements of above- and below-ground biomass. Clim. Chang. 2008, 86, 375-396. [CrossRef]

39. Ma, W.H.; Fang, J.; Yang, Y.; Maimaiti, A. Biomass carbon stocks and their changes in northern China's grasslands during 1982-2006. Sci. China Life Sci. 2010, 53, 841-850. [CrossRef] [PubMed]

40. Fang, J.Y.; Guo, Z.D.; Piao, S.L.; Chen, A.P. Estimation of Land Vegetation Carbon Sink in China from 1981-2000. Sci. China Press 2007, 37, 804-812.

41. Cao, Y.; Bai, Z.; Zhou, W.; Zhang, X. Characteristic analysis and pattern evolution on landscape types in typical compound area of mine agriculture urban in Shanxi Province, China. Environ. Earth Sci. 2016, 75, 585. [CrossRef]

42. Cao, Y.; Bai, Z.; Zhou, W.; Zhang, X. Analyses of traits and driving forces on urban land expansion in a typical coal-resource-based city in a loess area. Environ. Earth Sci. 2016, 75, 1191. [CrossRef]

43. Liu, X.H.; Dong, G.H.; Xue, Z.S.; Lu, X.U.; Jiang, M.; Zhang, Y. Carbon sequestration potential change after marshlands conversion to croplands in the Northeast China between 1982 and 2010. Ecol. Eng. 2014, 70, 402-405. [CrossRef] 
44. Novara, A.; Gristina, L.; Sala, G.; Galati, A.; Crescimanno, M.; Cerda, A.; Badalamenti, E.; La Mantia, T. Agricultural land abandonment in Mediterranean environment provides ecosystem services via soil carbon sequestration. Sci. Total Environ. 2017, 576, 420-429. [CrossRef] [PubMed]

45. Cao, Y.; Dallimer, M.; Stringer, L.C.; Bai, Z.; Siu, Y.L. Land expropriation compensation among multiple stakeholders in a mining area: Explaining “skeleton house" compensation. Land Use Policy 2017, 74, 97-110. [CrossRef]

46. Novara, A.; La Mantia, T.; Barbera, V.; Gristina, L. Paired-site approach for studying soil organic carbon dynamics in a Mediterranean semiarid environment. Catena 2012, 89, 1-7. [CrossRef]

47. Post, W.M.; Kwon, K.C. Soil carbon sequestration and land-use change: Processes and potential. Glob. Chang. Biol. 2000, 6, 317-327. [CrossRef]

48. Deng, L.; Wang, G.L.; Liu, G.B.; Shangguan, Z.P. Effects of age and land-use changes on soil carbon and nitrogen sequestrations following cropland abandonment on the Loess Plateau, China. Ecol. Eng. 2016, 90, 105-112. [CrossRef]

49. Mukhopadhyay, S.; Maiti, S.K.; Masto, R.E. Use of Reclaimed Mine Soil Index (RMSI) for screening of tree species for reclamation of coal mine degraded land. Ecol. Eng. 2013, 57, 133-142. [CrossRef]

50. Kumar, S.; Maiti, S.K.; Chaudhuri, S. Soil development in 2-21 years old coalmine reclaimed spoil with trees: A case study from Sonepur-Bazari opencast project, Raniganj Coalfield, India. Ecol. Eng. 2015, 84, 311-324. [CrossRef]

51. Frouz, J. Effects Of Soil Development Time And Litter Quality on Soil Carbon Sequestration: Assessing Soil Carbon Saturation with a Field Transplant Experiment Along a Post-Mining Chronosequence. Land Degrad. Dev. 2017, 28, 664-672. [CrossRef]

52. Sourkova, M.; Frouz, J.; Fettweis, U.; Bens, O.; Huttl, R.F.; Santruckova, H. Soil development and properties of microbial biomass succession in reclaimed post mining sites near Sokolov (Czech Republic) and near Cottbus (Germany). Geoderma 2005, 129, 73-80. [CrossRef]

53. Tiwary, A.; Sinnett, D.; Peachey, C.; Chalabi, Z.; Vardoulakis, S.; Fletcher, T.; Leonardi, G.; Grundy, C.; Azapagic, A.; Hutchings, T.R. An integrated tool to assess the role of new planting in PM10 capture and the human health benefits: A case study in London. Environ. Pollut. 2009, 157, 2645-2653. [CrossRef] [PubMed]

54. Yang, B.; Bai, Z.; Zhang, X. Carbon Emission from Land Damage Area in Large Opencast Coal Mines: A Case Study of Pingshuo Mining Area, China. China Land Sci. 2017, 31, 59-69.

55. Maraseni, T.N.; Mitchell, C. An assessment of carbon sequestration potential of riparian zone of Condamine Catchment, Queensland, Australia. Land Use Policy 2016, 54, 139-146. [CrossRef]

56. Bai, Z.; Yang, Q.; Bai, J. Disscussions of source control and process supervision for green mine construction. China Min. Mag. 2018, 27, 75-79.

57. He, Z.W.; Bai, Z.K.; Zhang, J.D.; Liu, X.T.; Wang, J.; Zhou, W.; Wang, J.M. Status and Stage Features of Land Reclamation Supervision in China. China Land Sci. 2012, 26, 56-59. 